\title{
Comparison of injection drotaverine and injection valethamate bromide on duration and course of labor
}

\section{Pradnya Rajendra Changede*}

\begin{abstract}
Department of Obstetrics and Gynaecology, Lokmanya Tilak Municipal Medical College and General Hospital,
\end{abstract} Mumbai, India

Received: 19 March 2016

Accepted: 23 April 2016

\section{*Correspondence:}

Dr. Pradnya Rajendra Changede,

E-mail: pradnyachangede@gmail.com

Copyright: (C) the author(s), publisher and licensee Medip Academy. This is an open-access article distributed under the terms of the Creative Commons Attribution Non-Commercial License, which permits unrestricted non-commercial use, distribution, and reproduction in any medium, provided the original work is properly cited.

\begin{abstract}
Background: Numerous drugs have been used to shorten the active phase of labor. How rationale is it to use these drugs to shorten the active phase of labor? Do they really shorten the duration of labor? What adverse effects do they have on the baby and the mother? These questions were the basis to perform the present study of comparing two of such drugs, injection drotaverine and injection Valethamate bromide with control subjects.

Methods: This was a prospective study conducted in a tertiary center over a span of 2 years. 120 patients were enrolled in the study group. These patients were randomly allotted in 3 groups: a. 60 patients (30 primigravida and 30 multigravida) - control group (no drug given), b. 30 patients (15 primigravida and 15 multigravida) - drotaverine (DROTIN) group, c. 30 patients (15 primigravida and 15 multigravida) - valethamate bromide (EPIDOSIN) group. A statistical test, 'unpaired t test', was used to test the results for statistical significance. A x2 (chi square) test was used to test results of side effects for statistical significance.

Results: The mean duration of active phase of first stage of labor was significantly shorter in the drotaverine and valethamate bromide groups as compared to control group in both primigravida and multigravida patients. Conclusions: The rate of cervical dilatation under the influence of valethamate bromide and drotaverine is significantly higher as compared to control group. In each group dilatation was faster in multigravida patients as compared to primigravida and it was fastest in the drotaverine group.
\end{abstract}

Keywords: Labor, Drotaverine, Valethamate Bromide

\section{INTRODUCTION}

The concept of "active management of labor" was introduced by Professor O'Driscoll at the National Maternity Hospital; Dublin. ${ }^{1}$ Following this obstetricians have changed their outlook regarding first stage of labor. Attempts to accelerate labor and thereby shorten its duration without jeopardizing maternal or fetal outcome are welcome to both the patient and the obstetrician. Some of the drugs that have been used are Hyoscine Nbutyl bromide, Phloroglucinol, Camylofin dihydrochloride and Valethamate bromide. Many of these due to their anticholinergic properties cause tachycardia and other undesirable side effects. Drotaverine, a relatively newer spasmolytic is claimed to cause cervical dilatation without causing side effects. It acts by inhibiting phosphodiesterase IV enzyme. Due to its neurotropic (atropine) like action and musculotropic (papaverine) like action Valethamate bromide an antispasmodic helps in cervical dilatation The present study was conducted to find whether drugs like injection Drotaverine and Injection Valethamate Bromide shorten the first stage of labor more efficaciously than in control group.

\section{Aims and objectives}

1. To compare the duration of active 1st phase of labor in control group and compare it with cervical dilators drotaverine and valethamate bromide. 
2. To compare the rate of cervical dilatation in these three groups and to assess its relation to the gravidity of the patient.

3. To assess the side effects of the drug on the mother and the fetus.

\section{METHODS}

This was a prospective study conducted in a tertiary center over a span of 2 years. 120 patients were enrolled in the study group after taking their informed, written and valid consent.

\section{Inclusion criteria}

120 women at 37 weeks to 41 weeks of pregnancy with vertex presentation in established labor; which was defined as effective uterine contraction, good cervical effacement and $3 \mathrm{~cm}$ of cervical dilatation.

\section{Exclusion criteria}

Women with previous uterine scars, malpresentations, multiple pregnancies, cephalopelvic disproportion, preeclampsia, antepartum hemorrhage, meconium stained amniotic fluid, contraindication to use of injection Drotaverine and or injection Valethamate bromide.

\section{Study procedure}

120 patients were randomly allotted in 3 groups by computer randomization.

1. 60 patients (30 primigravida and 30 multigravida) control group (no drug given).

2. 30 patients (15 primigravida and 15 multigravida) drotaverine (DROTIN) group (Injection drotaverine $40 \mathrm{mg}$ was given intramuscular at intervals of 3 hours, starting at $3 \mathrm{~cm}$ cervical dilatation, and maximum of 3 doses were given).

3. 30 patients ( 15 primigravida and 15 multigravida) valethamate bromite (EPIDOSIN) group (Injection epidosin $8 \mathrm{mg}$ was given intramuscular, starting at 3 $\mathrm{cm}$ cervical dilatation, and repeated 1hourly to a maximum of 3 doses).

2 hourly per vaginal examination were carried out to assess the progress of labor. There were no significant differences in the gravidity, age and duration of gestation.

A statistical test, 'unpaired t test', was used to test the results for statistical significance.

The neonatal and maternal side effects were observed. APGAR score was taken at $1 \mathrm{~min}, 5 \mathrm{~min}$ and at $10 \mathrm{~min}$. Following maternal side effects were noted headache, dryness of mouth, tachycardia and flushing of face. A $\mathrm{x}^{2}$ (chi square) test was used to test results of side effects for statistical significance.
A brief description of pharmacology of the drugs used is given below.

\section{Drotaverine (DROTIN)}

Drotaverine an analogue of papaverine is a benzylisoquinoline derivative, with smooth muscle relaxant properties.

Mechanism of action: Drotaverine has spasmolytic and vasodilating action. It exerts its action by inhibiting phosphodiesterase enzyme IV which leads to a decrease in cyclic AMP level and reduction in calcium ions $(\mathrm{Ca} 2+)$. The reduction of calcium ions dilates the muscles and blood vessels strongly and relieves spasm of smooth muscles.

Metabolism: Drotaverine appears to undergo extensive first-pass metabolism. It is readily metabolized in the liver by O-deethylation to mono- and di-phenolic compounds and their corresponding glucuronic acid derivatives.

Excretion: Drotaverine is metabolized in the liver and it is excreted in the urine and faeces. The half-life of drotaverine is approximately 7 to 12 hours.

Side effects: Hypotension, tachycardia, headache and vertigo and acute attacks of porphyria.

\section{Valethamate bromide (EPIDOSIN)}

Valethamate bromide is also known as Diethyl (methy1) (2-(3-methy1-2-phenylvaleryloxy) ethy1) ammonium bromide. It is an anticholinergic agent, used as a smooth muscle relaxant.

Mechanism of action: It has both a central and a peripheral antimuscarininc action, which is a competitive inhibitor of acetylcholine at the muscarinic receptors.

Pharmacokinetics: After IM administration, onset of action occurs in about $20-30$ minutes. Plasma half-life is 4 hours. It crosses the placenta and is secreted in the breast milk. It is completely metabolized in the liver and is excreted in the urine as both unchanged drug and metabolites.

\section{Dosage and routes of administration: 4-8 mg IM or IV.}

Drug interactions: The effects of valethamate are enhanced by the concomitant administration of other drugs with antimuscarinic properties such as some histamines, butyrophenones, phenothiazines and tricyclic antidepressants. There is also reduction in gastric motility which may affect the absorption of certain drugs.

Adverse effects: Due to its anticholinergic action dryness of mouth, thirst, reduced bronchial secretions, dilatation of the pupil (mydriasis) with loss of accommodation 
(cycloplegia) flushing and dryness of skin and palpitations. Other rare side effects include drug rashes, CNS symptoms like nervousness, giddiness; hypersensitivity.

Treatment of toxicity: Continuous ECG, vital signs monitoring, ventilator supports, external cooling measures for hyperpyrexia, Diazepam for convulsions, and symptomatic treatment. To overcome anticholinergic effects, judicious use of physostigmine can be done 1-3 mg IM or SC, repeated every 4-6 hour.

\section{RESULTS}

Table 1: Duration of active first stage and rate of cervical dilatation in primigravida.

\begin{tabular}{|llll|}
\hline & Drotin & Epidosin & Control \\
\hline $\begin{array}{l}\text { No of } \\
\text { patient's }\end{array}$ & 15 & 15 & 30 \\
\hline $\begin{array}{l}\text { Mean } \\
\text { duration of } \\
\text { active phase } \\
\text { of first stage } \\
\text { (min) }\end{array}$ & 110.7 & 156.7 & 229.7 \\
\hline $\begin{array}{l}\text { Difference } \\
\text { of means } \\
\text { (min) }\end{array}$ & 119 & 73 & \\
\hline $\begin{array}{l}\text { Rate of } \\
\text { Cervical }\end{array}$ & 3.8 & 2.68 & \\
$\begin{array}{l}\text { Dilatation } \\
\text { (cm/hr) }\end{array}$ & P $<0.001$ & P $<0.001$ & \\
\hline P value & $\begin{array}{l}\text { Highly } \\
\text { significant }\end{array}$ & $\begin{array}{l}\text { Highly } \\
\text { significant }\end{array}$ \\
\hline Significance & \\
\hline
\end{tabular}

\section{Age group}

The average age in primigravida patients in control group was 23.4yrs (range 19yrs to 32yrs) whereas in multigravida it was $25.9 \mathrm{yrs}$ (range $21 \mathrm{yrs}$ to $34 \mathrm{yrs}$ ).

The average age in primigravida patients in valethamate bromide group was 24.6yrs (range 19yrs to 30yrs) whereas in multigravida it was 26yrs (range 20yrs to $32 \mathrm{yrs})$.

The average age in primigravida patients in drotaverine group was 25.9yrs (range 21yrs to 34 yrs) whereas in multigravida it was $28.2 \mathrm{yrs}$ (range $23 \mathrm{yrs}$ to $38 \mathrm{yrs}$ ).

\section{Gestational age}

The average gestational age in primigravida patients in control group was $38.6 \mathrm{wks}$ whereas in multigravida it was 39wks.

The average gestational age in primigravida patients in valethemate bromide group was $38.6 \mathrm{wks}$ whereas in multigravida it was $38.3 \mathrm{wks}$. The average age in primigravida patients in drotaverine group was $39 \mathrm{wks}$ whereas in multigravida it was $38.6 \mathrm{wks}$.

Table 2: Duration of active first stage and rate of cervical dilatation in multigravida.

\begin{tabular}{|llll|}
\hline & Drotin & Epidosin & Control \\
\hline $\begin{array}{l}\text { No of } \\
\text { patient's }\end{array}$ & 15 & 15 & 30 \\
\hline $\begin{array}{l}\text { Mean } \\
\text { duration of } \\
\text { active phase } \\
\text { of first stage } \\
\text { (min) }\end{array}$ & 96.2 & 126.3 & 173.2 \\
\hline $\begin{array}{l}\text { Difference } \\
\text { of means } \\
\text { (min) }\end{array}$ & 77 & 46.9 & \\
\hline $\begin{array}{l}\text { Rate of } \\
\text { Cervical }\end{array}$ & 4.36 & 3.3 & \\
$\begin{array}{l}\text { Dilatation } \\
\text { (cm/hr) }\end{array}$ & P $<0.001$ & P $<0.001$ & \\
\hline P value & $\begin{array}{l}\text { Highly } \\
\text { significant }\end{array}$ & $\begin{array}{l}\text { Highly } \\
\text { significant }\end{array}$ \\
\hline Significance & & \\
\hline
\end{tabular}

\section{Duration of active first stage and rate of cervical dilatation in primigravida}

In primigravida the mean duration of active phase of first stage of labor was $229.7 \mathrm{~min}, 156.7 \mathrm{~min}$ and $110.7 \mathrm{~min}$ in control group injection, valethamate group and injection drotaverine group respectively. The $\mathrm{p}$ value $=0.001$ was highly significant (Table 1).

\section{Duration of active first stage and rate of cervical dilatation in multigravida}

In multigravida the mean duration of active phase of first stage of labor was $173.2 \mathrm{~min}, 126.3 \mathrm{~min}$ and $96.2 \mathrm{~min}$ in control group injection, valethamate group and injection drotaverine group respectively. The $\mathrm{p}$ value $=0.001$ was highly significant (Table 2).

Table 3: Duration of second and third stage of labor.

\begin{tabular}{|llll|}
\hline Gravidity & Group & $\begin{array}{l}\text { Mean } \\
\text { duration } \\
\text { of second } \\
\text { stage } \\
(\text { min) }\end{array}$ & $\begin{array}{l}\text { Mean } \\
\text { duration of } \\
\text { third stage } \\
\text { (min) }\end{array}$ \\
\hline \multirow{2}{*}{ Primigravida } & Control & 20.7 & 7.1 \\
\cline { 2 - 4 } & Epidosin & 24.1 & 7 \\
\cline { 2 - 4 } Multigravida & Drotin & 21.8 & 8 \\
\hline & Control & 20.1 & 6.63 \\
\cline { 2 - 4 } & Epidosin & 18.6 & 9.4 \\
\cline { 2 - 4 } & Drotin & 16 & 7.5 \\
\hline
\end{tabular}


Table 4: Maternal side effects.

\begin{tabular}{|llllll|}
\hline Group & No of patient & Headache & Dryness of mouth & Tachycardia & Flushing of face \\
\hline Epidosin & 30 & 4 & 5 & 12 & 5 \\
\hline Drotin & 30 & 3 & - & 2 & - \\
\hline
\end{tabular}

Table 5: Comparison of various studies.

\begin{tabular}{|c|c|c|c|c|c|c|}
\hline \multirow[t]{3}{*}{ Study } & \multirow[t]{3}{*}{ Drug } & \multirow{2}{*}{\multicolumn{2}{|c|}{$\begin{array}{l}\text { No of } \\
\text { patients }\end{array}$}} & \multicolumn{2}{|c|}{$\begin{array}{l}\text { Mean duration of first stage } \\
\text { (min) }\end{array}$} & \multirow[t]{3}{*}{ Conclusion } \\
\hline & & & & & M & \\
\hline & & $\mathbf{P}$ & M & & & \\
\hline \multirow[t]{2}{*}{ Kaur D et al } & \multirow{2}{*}{$\begin{array}{l}\text { Drotin } \\
\text { Epidosin }\end{array}$} & 92 & 158 & 143.9 & 99.7 & \multirow{2}{*}{$\begin{array}{l}\text { Drotaverine better } \\
\text { than epidosin and has } \\
\text { less side effects }\end{array}$} \\
\hline & & 20 & 50 & 180.4 & 146.6 & \\
\hline \multirow{2}{*}{$\begin{array}{l}\text { Sharma JB et } \\
\text { al }\end{array}$} & Drotin & 50 & & 193.96 & & \multirow{2}{*}{$\begin{array}{l}\text { Drotaverine better } \\
\text { than epidosin and has } \\
\text { less side effects }\end{array}$} \\
\hline & Epidosin & 50 & & 220.68 & & \\
\hline \multirow{2}{*}{$\begin{array}{l}\text { Khosla AH et } \\
\text { al }\end{array}$} & \multirow[b]{2}{*}{ Drotin } & 66 & 34 & 208.8 & 112.05 & \multirow[b]{2}{*}{$\begin{array}{l}\text { Drotin and epidosin } \\
\text { better than control in } \\
\text { primigravida and } \\
\text { multigravida. } \\
\text { Epidosin more } \\
\text { effective than Drotin } \\
\text { in primigravida but } \\
\text { not in multigravida }\end{array}$} \\
\hline & & 68 & 32 & 145.9 & 104.3 & \\
\hline \multirow[t]{2}{*}{ Meena $\mathrm{T}$ et al } & \multirow[t]{2}{*}{ Drotin } & 31 & 19 & 196.9 & 127.6 & \multirow{2}{*}{$\begin{array}{l}\text { Drotin and epidosin } \\
\text { are equally effective } \\
\text { in primigravida but } \\
\text { drotin more effective } \\
\text { in multigravida. }\end{array}$} \\
\hline & & & 23 & 188.1 & 182.7 & \\
\hline \multirow[t]{2}{*}{ Roy et al } & \multirow{2}{*}{$\begin{array}{l}\text { Drotin } \\
\text { Control }\end{array}$} & 100 & & 148.9 & 99.5 & \multirow{2}{*}{$\begin{array}{l}\text { Drotin better than } \\
\text { control, more } \\
\text { effective in } \\
\text { multigravida. }\end{array}$} \\
\hline & & 100 & & 331.6 & 227.9 & \\
\hline \multirow{2}{*}{ Kuruvila et al } & Epidosin & 60 & & & & \multirow[b]{2}{*}{$\begin{array}{l}\text { No statistical } \\
\text { differences in the rate } \\
\text { of cervical dilatation } \\
\text { of the groups. } \\
\text { Maternal tachycardia } \\
\text { more in epidosin } \\
\text { group. }\end{array}$} \\
\hline & Control & 60 & & & & \\
\hline \multirow{2}{*}{$\begin{array}{l}\text { Batukan AC } \\
\text { et al }\end{array}$} & Epidosin & & & 210.3 & 187.1 & \multirow{2}{*}{$\begin{array}{l}\text { Epidosin better than } \\
\text { control in } \\
\text { primigravida but not } \\
\text { in multigravida. }\end{array}$} \\
\hline & Control & & & 287.1 & 241.9 & \\
\hline $\begin{array}{l}\text { Singh } \mathrm{KC} \text { et } \\
\text { al }\end{array}$ & Drotin & & & & & $\begin{array}{l}\text { Drotin better than } \\
\text { control in } \\
\text { accelerating labor. } \\
\text { Atonic PPH more } \\
\text { common with Drotin. }\end{array}$ \\
\hline \multirow[t]{2}{*}{ Present study } & Drotin & 15 & 15 & 110.7 & 96.2 & \multirow[b]{2}{*}{$\begin{array}{l}\text { Drotaverine better } \\
\text { than epidosin and has } \\
\text { less side effects and } \\
\text { both better than } \\
\text { control group }\end{array}$} \\
\hline & & 15 & 15 & 156.7 & 126.3 & \\
\hline
\end{tabular}

$\mathrm{P}=$ Primigravida; $\mathrm{M}=$ Multigravida 


\section{Duration of second and third stage of labor}

There was no significant difference between the duration of second and third stage of labor in all the three groups both in primigravida and multigravida (Table 3 ).

\section{Neonatal side effects}

There were no observed side effects in the neonate in the control and the drotaverine group. Two neonates in the valethamate bromide group had low Apgar score at one min but had normal scores at $10 \mathrm{~min}$. These neonates also had tachypnoea which resolved in $24 \mathrm{hrs}$.

\section{DISCUSSION}

Attempts to accelerate labor and thereby shorten its duration without jeopardizing maternal or foetal outcome are beneficial for the patient and for the obstetrician. The rate of cervical dilatation and uterine activity are the two important factors that determine the duration of labor.

In our study the average age in primigravidae patients in control group was $23.4 \mathrm{yrs}$ whereas in multigravida it was $25.9 \mathrm{yrs}$. The average age in primigravida patients in valethamate bromide group was 24.6yrs whereas in multigravida it was 26yrs. The average age in primigravida patients in drotaverine group was $25.9 \mathrm{yrs}$ whereas in multigravida it was $28.2 \mathrm{yrs}$. In the study conducted by Batukan AC in Turkey the average maternal age for valethamate bromide group was $25.5+5.7$ years and in control group was $26.4+6.3$ years. ${ }^{2}$ In the study conducted at Amritsar by D. Kaur the average maternal age in the Epidosin group was $25.18+4.08$ years and in the Drotaverine group was $24.97+3.90$ years. $^{3}$ The average maternal age in our study are comparable to the above studies and fall within the range.

The average gestational age in primigravida patients in control group was $38.6 \mathrm{wks}$ whereas in multigravida it was 38.4 wks. In the valethamate bromide primigravida group it was $38.6 \mathrm{wks}$ whereas in multigravida it was 38.3 wks.

The average age in primigravida patients in drotaverine group was $39 \mathrm{wks}$ whereas in multigravida it was 38.6wks. Batukan AC study in Turkey comprised of 98 patients with mean gestational age at delivery $39.0+1.5$ in the study group vs. $38.9+1.8$ weeks in the control group. ${ }^{2}$

Kaur D and Kaur R had a total of 300 patients in their study group with gestational age at delivery being $38.6+1.06$ weeks in the drotaverine group and $38.86+$ 1.16 weeks. ${ }^{3}$ In the study conducted at Peshawar by Tabassum $\mathrm{S}$ the gestational age in the drug group was 38.64 weeks vs 38.72 in the control group. ${ }^{4}$ The gestational age in our study and in the above mentioned articles are comparable.
Kuruvila $\mathrm{S}$ et al from Vellore conducted a trial of valethamate bromide, among 60 consecutive primigravida and 60 consecutive multigravida. His analysis showed that valethamate bromide did not appear to have any effect on the rate of cervical dilatation. Administration of the drug did not have any beneficial effect on the progress of labor and was also associated with unpleasant side effects including flushing, dryness of the mouth and tachycardia. He did not recommend it as a spasmolytic to hasten the first stage of labor. ${ }^{5}$ However other studies such as the one carried out by Batukan AC et al from Turkey showed that the active phase of labor was significantly shorter in the valethamate bromide group than in the placebo group $(200.2+88.3$ vs. $267.2+131.3$ minutes; $\mathrm{p}=0.04)$. Valethamate bromide shortened the active phase of labor in primigravida patients $(210.3+93.5$ vs. $287.1+130.3$ minutes; $\mathrm{p}=0.015$ ) but not in multigravida patients $(187.1+81.4$ vs. $241.9+131.1$ minutes; $\mathrm{p}=0.11)$. He concluded that Valethamate bromide administered during the active phase of labor significantly decreases the duration of the first stage of labor when compared to the placebo group. In our study in the Valethamate Bromide group the mean duration of active first stage was 156.7 min in primigravida compared to $229.7 \mathrm{~min}$ in the control group. The drug shortened the first stage by a mean of 73 minutes which was statistically significant $(\mathrm{p}<0.001)$. In case of multigravida it was $126.3 \mathrm{~min}$ compared to 173.2 min in the control group, the difference in the means being $46.83 \mathrm{~min}$. This was also statistically significant compared to control group. Thus in our study we found out that valethamate bromide was very effective in curtailing the active phase of first stage of labor. Kuruvila $\mathrm{S}$ in his study found that many of his patients that received valethamate bromide had side effects such as dryness of mouth, flushing and maternal tachycardia. However there was no fetal complication. In our study headache was present in 4 patients, dryness of mouth in 5 patients, flushing was observed in 5 patients. However maternal tachycardia was seen in $40 \%$ of patients. This was significantly higher as compared to control subjects.

Goswami et al compared Drotaverine and epidosin as regards to effect on labor. ${ }^{6}$ They concluded that drotaverine shortens the duration of first stage by $2.8 \mathrm{hrs}$ as compared to a control group and it also hastens cervical dilatation by the rate of 1.3 to $2.04 \mathrm{~cm} / \mathrm{hr}$ as compared to a control group. In our study, drotaverine hastened cervical dilatation by $1.2 \mathrm{~cm} / \mathrm{hr}$ in primigravida patients and by $1.03 \mathrm{~cm} / \mathrm{hr}$. in multigravida patients as compared to valethamate bromide group.

Demeter and Blasko observed that drotaverine shortens the dilatation stage of labor by $53 \mathrm{~min}$ as compared to a control group. ${ }^{7}$ Duration of second and third stage was not prolonged. Drotaverine does not interfere with the uterine contractility. Incidence of cervical tears was also significantly less in the drotaverine group. 
In a study from Rothak by Khosla $\mathrm{AH}$ the mean duration of first stage of labor after $4 \mathrm{~cm}$ dilatation in primigravida patients was $145 \mathrm{~min}, 208 \mathrm{~min}$ and $318 \mathrm{~min}$ in epidosin, drotaverine and control group respectively. ${ }^{8}$ In case of multigravida patients it was $104 \mathrm{~min}, 112 \mathrm{~min}$, and $230 \mathrm{~min}$ in epidosin, drotaverine and control group respectively. In their study both drotaverine and valethamate bromide caused highly significant reduction in duration of first stage as compared to controls in primigravida patients as well as in multigravida patients. Valethamate bromide was significantly more effective than drotaverine in primigravida patients but not in multigravida patients in their study. In our study the mean duration of first stage of labor after $3 \mathrm{~cm}$ dilatation in primigravida was $156.7 \mathrm{~min}, \quad 110.7 \mathrm{~min}$ and $229.7 \mathrm{~min}$ in epidosin, drotaverine and control group respectively. In case of multigravida it was $126.3 \mathrm{~min}, 96.2 \mathrm{~min}$, and $173.2 \mathrm{~min}$ in epidosin, drotaverine and control group respectively. Applying unpaired ' $t$ ' test to our study population we found out that individually both epidosin and drotaverine group shortened the duration of first stage of labor significantly compared to control group in both primigravida and multigravida patients. When comparing drotaverine to epidosin group the difference between the first stage of labor was highly significant in primigravida $(\mathrm{p}<0.001)$ and multigravida $(\mathrm{p}<0.05)$. Drotaverine fared better compared to epidosin in our study.

A similar study was conducted by Thapa M. ${ }^{9}$ In this study the injection to delivery interval was studied between drotaverine and epidosin group. In multigravidae patients of drotaverine group the interval was shorter $(\mathrm{p}=0.72)$. They found out that in primigravidae both the drugs had similar efficacy in accelerating active stage of labor. They reached to a conclusion that the efficacy of shortening active labor was statistically similar with drotaverine and valethamate bromide.

Roy A in his study observed that the mean durations of active phase of labor in primigravida and multigravida were 148.9 minutes and 99.5 minutes in drotaverine group whereas in control group were 331.6 minutes and 227.9 minutes respectively. ${ }^{10} \mathrm{He}$ concluded that drotaverine was highly effective in reducing the duration of active phase of labor by hastening cervical dilatation; more effective when it was given in more dilated cervix than with less dilatation and more effective in multigravida than in primigravida. Another study from Singh KC found out that in the drotaverine group of patients there was a mean $15 \%$ reduction in the duration of the first stage of labor and a mean $19 \%$ reduction in the second stage. ${ }^{11} \mathrm{He}$ observed that the maximum shortening of the first stage (28\%) occurred when drotaverine was administered when cervical dilatation was $4 \mathrm{~cm}$. In their patients there were no adverse fetal effects, but the incidence of atonic postpartum hemorrhage was more common in the drotaverine group. He concluded that drotaverine hydrochloride is safe and effective in accelerating labor, but not effective in lessening labor pain. In the study conducted by Sharma et al he found out that the injection-to-delivery interval was significantly reduced in the drotaverine group (193.96min) in contrast to the valethamate group (220.68 min) and control group (412.84 min). ${ }^{12}$ He concluded that both intramuscular drotaverine hydrochloride and valethamate bromide are effective in acceleration of labor; however, drotaverine accelerates labor more rapidly and is associated with less side effects. In our patients there was reduction in the first stage of labor in the drotaverine group compared to controls. However there was no statistically significant difference in the second and third stages of labor. In our patients maternal tachycardia was seen to be more common in the epidosin group than the drotaverine or control group. Other side effects were minor and occurred in a similar frequency. The difference in the rates of cervical dilatation are statistically significant and we have found out that drotaverine is a better cervical dilator compared to valethamate bromide (Table 5).

\section{CONCLUSION}

Drotaverine and Valethamate bromide both are effective individually as cervical dilators to shorten the active phase of first stage. Drotaverine is a potent and very effective cervical dilator; its potency is significantly more than that of valethamate bromide.

The rate of cervical dilatation under the influence of valethamate bromide and drotaverine was significantly higher as compared to control group. In each group dilatation was faster in multigravida patients as compared to primigravida and it was fastest in the drotaverine group.

Drotaverine is a safe drug without any significant fetal or maternal side effects. The commonest side effect was maternal tachycardia in patients who were given valethamate bromide.

Funding: No funding sources

Conflict of interest: None declared

Ethical approval: The study was approved by the Institutional Ethics Committee

\section{REFERENCES}

1. O’Driscoll K, Stronge JM, Minogue M. Active management of labor, British Medical Journal. 1973;3:135-8.

2. Batukan AC, Özgün MT, Türkyılmaz C. The effect of valethamate bromide in acceleration of labor: a double-blind, placebo-controlled trial, Journal of the Turkish German Gynecological Association. 2006;7(3):202-5.

3. Kaur D, Kaur R. Comparison of Drotaverine and Epidosin in first stage of labor, Journal Obstetrics and Gynecology India. 2003;53(5):449-52.

4. Tabassum S, Afridi B, Aman Z. Phloroglucinol for Acceleration of Labor: Double blind, randomized 
controlled trial, Journal of Pakistan Medical Association. 2005;55(7):270-3.

5. Kuruvila S, Jasper P, Peedicayil A. A randomized controlled trial of valethamate bromide in acceleration of labor, International Journal of Gynecology and Obstetrics. 1992;38(2):93-6.

6. Goswami B, Sarkar M., Biswas B. Efficacy of drotaverine and valethamate bromide in active management of labor, International Journal of Gynecology and Obstetrics. 2000;70(3):37.

7. Demeter J, Blasko S, The effect of intramuscularly administered drotaverine on the dilatation stage of uncomplicated deliveries, Obstetrics and Gynecology. 1998;3:723-37.

8. Khosla AH, Bala I, Dahiya K. A comparative study of the efficacy of Valethamate bromide with
Drotaverine in normal labor, Journal Obstetrics and Gynecology India. 2003;53(6):568-70.

9. Thapa M, Saha R, Pradhan A. Effectiveness of drotaverine hydrochloride in progression of labor, Nepal Journal Obstetrics Gynecology. 2007;2(2):911.

10. Roy A, Patra KK, Mukhopadhyay S, et al. Study of drotaverine on first stage of labor and pregnancy outcome. S J Indian Med Assoc. 2007;105(8):450-2.

11. Singh KC, Jain P, Goel N. Drotaverine hydrochloride for augmentation of labor, International journal of gynaecology and obstetrics 2004;84(1):17-22.

12. Sharma JB, Pundir P, Kumar A. Drotaverine hydrochloride vs. valethamate bromide in acceleration of labor. International Journal of Gynecology and Obstetrics. 2001;74(3):255-60.

Cite this article as: Changede PR. Comparison of injection drotaverine and injection valethamate bromide on duration and course of labor. Int $\mathbf{J}$ Reprod Contracept Obstet Gynecol 2016;5:1836-42. 